\title{
"Human Habitation or Economic Life of their Own": The Definition of Features Between History, Technology and the Law
}

\section{Sondra Faccio ${ }^{1}$ (i)}

Published online: 20 October 2020

(c) The Author(s) 2020

\begin{abstract}
Article 121(3) of the United Nations Convention on the Law of the Sea (UNCLOS) establishes the regime of geographical features. It distinguishes the island from rocks, by defining the former as a naturally formed area of land, surrounded by water, which is above water at high tide; the latter as features 'which cannot sustain human habitation or economic life of their own.' The nature of the feature impacts on the sovereign rights recognized to the coastal States: if the feature is qualified as an island, it entitles the coastal State to 200 miles of exclusive economic zone and continental shelf, with undisputed right of exclusive exploitation of natural resources located within the area. By contrast, if the feature is qualified as a rock, the coastal State is only entitled to the territorial sea. Article 121(3) of UNCLOS and the formula 'rocks which cannot sustain human habitation or economic life of their own' have been subject to substantive interpretation for the first time by an international tribunal in The South China Sea Arbitration (Philippines v. China) Award. Starting from this Award, the present paper explores further the requisites of 'human habitation or economic life' and discusses what value shall be attributed to the technological development vis à vis historical excursus. The paper will review relevant States' practice, scholarly works and tribunals' decisions in the field and discuss how far (if any) could technological means go to support a feature's capacity.
\end{abstract}

Keywords Art. 121 (3) UNCLOS · Island · Rock · Exclusive economic zone (EEZ)

\footnotetext{
This paper was presented at the international conference "Islands and Remoteness in Geography, Law and Fiction" (21-22 November 2019) at the University of Verona (Italy).

Sondra Faccio

sondra.faccio@unitn.it

1 School of International Studies, University of Trento (Italy), Via Tommaso Gar, 14, 38122 Trento, Italy
} 


\section{Introduction}

Islands have been a recurrent source of inspiration for fiction and for mythology. They are linked to the unpredictable journey (i.e. the adventure) of heroes, who struggle to conquer, live or explore the sea and its treasures. In the Lord of the Flies by William Golding, "[e]yes shining, mouths open, triumphant," the boys "savored the right of domination" before the inhabited island where they landed. They were on "an island: ... with the sea on either side, and the crystal heights of air." 1 On the opposite, Daniel Defoe's hero, Robison Crusoe, saw his fate to his great affliction when he realised "that [he] was in an island environed every way with the sea," where he had to find a way to survive famine, cannibals and especially endless loneliness. $^{2}$ The island is the place of Shakespeare's The Tempest and the final destination of Homer's Odysseus wander, Ithaca, a place that he knows "no sweeter sight on earth."3

As in fiction, in the realm of international law an island represents a piece of land surrounded by waters, which can be the stage of some human activity. Indeed, according to article 121(3) of the United Nations Convention on the Law of the Sea (UNCLOS) "[a]n island is a naturally formed area of land, surrounded by water, which is above water at high tide;" rocks, by contrast, are features "which cannot sustain human habitation or economic life of their own."4

The capacity of features to be the stage of some human activity (in the words of the UNCLOS "sustain human habitation or economic life of their own") impacts on the sovereign rights recognized to the coastal State, as only "islands" entitle the coastal State to 200 miles of exclusive economic zone (EEZ) and continental shelf, with undisputed right of exclusive exploitation of natural resources.

The nature of features has acquired increasing significance starting from the Seventies of the past Century, when States began to exploit natural resources located in the seabed at relatively reduced costs, thanks to the development of higher technological means. ${ }^{5}$ Progressively, a number of coastal States have claimed the right of their geographical features to generate an EEZ beyond the 12 nautical miles of

\footnotetext{
1 William Golding (1954): 39: "Eyes shining, mouths open, triumphant, they savored the right of domination. They were lifted up: were friends. "There's no village smoke, and no boats," said Ralph wisely. "We'll make sure later; but I think it's uninhabited." "We'll get food," cried Jack. "Hunt. Catch things until they fetch us."

2 Defoe (1983): 46.

${ }^{3}$ Homer (1996): Book IX.21-32: "I am Odysseus, son of Laertes, known to the world/for every kind of craft-my fame has reached the skies/Sunny Ithaca is my home. Atop her stands our seamark/Mount Neriton's leafy ridges shimmering in the wind./Around her a ring of islands circle side-by-side, Dulichion, Same, wooded Zacynthus too, but mine lies low and away,/the farthest out to sea,/rearing into the western dusk/while the others face the east and breaking day. Mine is a rugged land but good for raising sons -/and I myself, I know no sweeter sight on earth than a man's own native country."

${ }^{4}$ UN General Assembly, The United Nations Convention on the Law of the Sea, opened for signature 10 December 1982, entered into force 16 November 1994. As of 9 March 2020, the Convention had 168 parties.

5 Faccio (2017): 623.
} 
the territorial sea, with the aim of expanding their access to natural resources. ${ }^{6}$ These claims were sometimes preceded by a veritable process of "islandization" of the feature, in the attempt to match the requisites established by article 121(3) of UNCLOS. $^{7}$

This practice has been rejected by the Tribunal in The South China Sea Arbitration Case (SCSA), which for the first-time interpreted article 121(3) of UNCLOS, arguing that "the status of a feature is to be determined on the basis of its natural capacity, without external additions or modifications intended to increase its capacity to sustain human habitation or an economic life of its own." 8 The SCSA was instituted by the Philippines against the People's Republic of China under Annex VII of the UNCLOS and concerned, among the others, the status of certain maritime features in the South China Sea.

Starting from the award in the SCSA case, the present paper would like to explore further the requisites of "sustain human habitation or economic life of their own." The paper will review relevant State practice on the matter and highlight the implication of SCSA Award, especially in cases where the feature does not "clearly fall within one category or the other" (island or rock). ${ }^{9}$ It will be argued that, in these cases, the application of technology to develop a feature's capacity cannot be excluded in principle, although technology shall not distort the nature of the feature itself and would require the benefits to be centered on the local community and its development, in line with the purpose that the EEZ and article 121(3) of UNCLOS were respectively intended to serve.

Accordingly, the paper is structured in five sections: (1) introduction (2) the analysis of the decision in the SCSA with specific focus on the formula "rocks which cannot sustain human habitation or economic life of their own," (3) the discussion of relevant State practice on the matter, (4) the application of article 121(3) to limit the exploitation of natural resources that does not benefit the local population, (5) conclusion.

\section{The Interpretation of the Formula "rocks which cannot sustain human habitation or economic life of their own" and Its Application in The South China Sea Arbitration Award}

The SCSA refers to a dispute between the Republic of the Philippines and the Popular Republic of China, regarding - among the others - the nature of the Chinese features Scarborough Shoal, Johnson Reef, Cuarteron Reef and Fiery Croos Reef,

\footnotetext{
6 Song (2010): 665.

7 For example, the case of the Japanese feature Okinotorishima and, partially, in the case of the Spratly Islands in the South China Sea. See Song (2010): 670; Silverstein (1990). According to the Tribunal in the The South China Sea Arbitration, Award of 12 July 2016 (hereinafter: SCSA), paras. 89, 140, 142, 306,511 , the Spratly has been subject to "significant" or "intense" modification.

8 SCSA paras. $511,541$.

9 SCSA para. 548.
} 
Gaven Reef (North), MecKennan Reef and Spratly islands, including Itu Aba, and their entitlement to an EEZ. ${ }^{10}$

The Arbitration Award under scrutiny concluded that the geographical features situated in the South China Sea are all "rocks," as they can sustain neither human habitation nor economic life in their naturally formed state. These features, therefore, are not entitled to the 200 nautical miles of EEZ and continental shelf in accordance with article 121(3) of UNCLOS.

The Tribunal arrived at this conclusion after a thoughtful analysis of the content of the above-mentioned article of UNCLOS, in accordance with the criteria set out in articles 31 and 32 of the Vienna Convention on the Law of Treaties (VCLT). ${ }^{11}$

The following sections will dwell on the part of the SCSA Award devoted to the textual, contextual, and teleological interpretation of article 121(3), and discuss its application to the features at stake in the case. The criterion of the "subsequent practice in the application of the treaty" provided for in article 31(3)(b) of the VCLT will be discussed in the "Subsequent Practice" sub-section and in the "Relevant State Practice and implications of The South China Sea Arbitration Award" section.

\section{Text}

First of all, the Tribunal established that the term "rocks" does not imply any geological or geomorphological criteria under the treaty. It follows that features composed of rock do not necessarily qualify as "rocks" for the purpose of article 121(3) of UNCLOS, provided that they are able to sustain human habitation or economic life of their own. Conversely, features made of material other than rocks (such as coral, sand, etc.), which have no capacity to sustain human habitation or economic life shall be qualified as "rocks."

The term "cannot" identifies the capacity of a feature, which shall derive from its natural conditions, prior to the onset of "significant" human modification. ${ }^{12}$ In this regard, the Tribunal established that, although historical evidence of absence of any human habitation or economic life in the past "may be relevant for establishing a feature's capacity", this does not provide per se sufficient evidence of the feature's incapacity to sustain any human habitation or economic life. It shall be ascertained case-by-case whether human habitation in the past has been prevented or ended by forces beyond the physical characteristics of the feature alone. ${ }^{13}$

The feature shall have the capacity to "sustain." The Tribunal considered that, in its ordinary meaning, "sustain" implies that the feature shall be able to support

\footnotetext{
${ }^{10}$ SCSA paras. 7-11. The proceeding was initiated by the Philippines under Annex VII of UNCLOS and took place in absentia of China. The features involved are currently occupied by China and represent only a few of the islands located in the South China Sea: Nansha island, for example, is excluded from the submission to the Tribunal, as well as other features that the Philippines occupies.

${ }^{11}$ Vienna Convention on the law of treaties (with annex), Vienna May 23, 1969, article 32, at https:// treaties.un.org/doc/Publication/UNTS/Volume\%201155/volume-1155-I-18232-English.pdf. Accessed 28 August 2020.

12 SCSA paras. 306, 508-511.

${ }^{13}$ SCSA paras. 483-484, 549.
} 
and provide the essentials entailing a minimal "proper standard" of living to some humans, over a period of time. ${ }^{14}$ Thus, a feature has the capacity to "sustain human habitation" when it has resources to support, maintain and provide food, drink and shelter to a community of persons to enable them to reside there permanently or habitually over an extended period of time. ${ }^{15}$

As to the term "or", the Tribunal has admitted that "human habitation" and "economic life" are linked in practical terms, however

a rock would be disentitled from an exclusive economic zone and continental shelf only if it were to lack both the capacity to sustain human habitation and the capacity to sustain an economic life of its own. ${ }^{16}$

Finally, the concept of "economic life of their own" implies the presence of resources capable to grant a minimal proper standard of living to some humans, as well as some level of human activity to exploit, develop and distribute them. ${ }^{17}$ In this regard, the role of the local population is pivotal as there will be no independent economic life, if the feature relies "predominantly on the infusion of outside resources," or if it serves "purely as an object for extractive activities, without the involvement of a local population." 18 According to the Tribunal, activities in the territorial sea could form part of the economic life of a feature provided that it "[has] some tangible link to the high-tide feature itself," through local population or otherwise. ${ }^{19}$ By contrast, any economic activity derived from a possible EEZ or continental shelf shall be excluded. ${ }^{20}$

\section{Context, Object and Purpose}

The contextual interpretation of article 121(3) confirms that the capacity and "the status of a feature must be assessed on the basis of its natural condition (emphasis added)." 21 According to the Tribunal, this reading is consistent with the "naturally

\footnotetext{
14 SCSA para. 487.

15 SCSA paras. $489,491$.

16 SCSA para. 496. The text remains open to the possibility that a feature may be able to sustain human habitation without offering no resources to support an economic life and vice versa. That is particularly true in the case of multiple islands. Contra, Van Dyke, Morgan, and Gurish (1988): 437: "[t]he reference in article 121(3) to "human habitation" and "economic life" indicate that something more than a purely objective geographical definition is required by the term "rock" (emphasis added)."

17 Faccio (2017): 633.

18 SCSA para. 500.

19 SCSA para. 503, 556.

20 SCSA, para. 502. In this regard, Elferink (2016) observed that this interpretation leads to a contradiction: "[w]hile the tribunal first concludes - correctly in the view of this author - that the word "or" between "human habitation" and "economic life of their own" implies that these requirements do not have to be met at the same time, the interpretation it offers of "economic life of their own" implies that this latter requirement as a general rule will only be met if the requirement of "human habitation" has been met. This makes the requirement of "economic life of their own" ancillary to the requirement of "human habitation", instead of these being two requirements that stand on an equal footing."

21 SCSA para. 508.
} 
formed area" wording also included in article 13 of the UNCLOS, which refers to low-tide elevations. ${ }^{22}$

With reference to the object and purpose of article 121(3), the Tribunal observed that this provision has been designed to serve as "counterpoint to the expanded jurisdiction of the exclusive economic zone." ${ }^{23}$ Indeed, the EEZ has the aim of extending the jurisdiction of States over the waters adjacent to their coasts to preserve the resources of those waters for the benefit of the population of the coastal State; but, such extension is justified only if the relevant feature is naturally capable of sustaining human habitation or economic life. Therefore, States cannot be "allowed to convert any rock incapable of sustaining human habitation or an economic life into a fully entitled island simply by the introduction of technology and extraneous materials." Otherwise, "the purpose of Article 121(3) as a provision of limitation would be frustrated" to the detriment of the common heritage of mankind. ${ }^{24}$

\section{Subsequent Practice}

The subsequent practice of States forms part of the general rule on interpretation set forth in article 31(3)(b) of the VCLT. ${ }^{25}$

The subsequent practice concerning the application of article 121(3) of the UNCLOS is significant and involves a number of State-parties to this Convention, including France, Japan and the New Zealand that claim 200 nautical miles EEZ for Clipperton Island, Okinotorishima, ${ }^{26}$ and the Kermadec Islands group, respectively. ${ }^{27}$ These examples concern features, which are comparably in size to the features subject to the SCSA and which are almost likely to be captured by the interpretation of article 121(3) of UNCLOS. ${ }^{28}$

Nonetheless, the Tribunal in SCSA only devoted two paragraphs (552-553) to the discussion of the State practice, concluding that in the present case "there is no

\footnotetext{
${ }^{22}$ UNCLOS, articles 13; 121(3). Contra, see Nordquist (2018): 188 and 189: "[t]he Arbitral Tribunal erroneously asserted, for instance, that 'Article 121(3) must... be interpreted in conjunction with... Article 13 concerning low-tide elevations', because of a perceived 'system of classifying features.'”.

23 SCSA paras. 516-517.

24 SCSA paras. 509, 518, 528, 529, 533. As to the purpose of article 121(3), see also: Nordquist and Phalen (2017). As to the common heritage of mankind, articles 136 and 140 of UNCLOS establish that the Area of seabed, ocean floor and subsoil thereof, beyond the limits of national jurisdiction are the common heritage of the mankind and activities in this Area are carried out for the benefit of mankind as a whole.

${ }^{25}$ Vienna Convention on the law of treaties (with annex), Vienna May 23, 1969, article 31(3): "[t]here shall be taken into account, together with the context: ... (b) Any subsequent practice in the application of the treaty which establishes the agreement of the parties regarding its interpretation."

26 Japan has also claimed $200 \mathrm{~nm}$ EEZ for Takeshima (Dokdo) in the Sea of Japan and for the Senkaku (Diao-yu-tai) Islands in the East China Sea, these two features are also subject of territorial disputes.

27 For more examples of relevant State practice see: Song (2018): 251-255.

28 Elferink (2016): “[a]n obvious example is Japan's Okinotorishima, which is comparable in size to the rocks on Scarborough Reef...;” Song (2018): 253: “[t]he Kermadec Islands consist of five insular formations, namely, Raoul, Macauley, Cheeseman, Curtis, and L'Esperance, which lie halfway between the Bay of Plenty, New Zealand, and Tonga. These islands are uninhabited, except for Raoul Island, where there is a permanently staffed meteorological, radio, and conservation station;" Rapport Folliot (1955).
} 
evidence for an agreement based upon State practice on the interpretation of Article 121(3) which differs from [the interpretation it provided for in the Arbitration]." ${ }^{29}$ As it will be discussed in the subsequent section, the lack of analysis of the State practice gave rise to significant criticism and could have the effect of weakening the authority of the Award with reference to the interpretation of article 121(3) of UNCLOS in the future.

\section{Application to the South China Sea Features}

The Tribunal established that evidence of physical conditions, such as vegetation, drinkable water and foodstuffs necessary for basic survival, will ordinarily suffice to confirm that the feature can sustain human habitation or economic life, except in the case of features that "fall close to the line," i.e. that are neither obviously habitable, nor inhabitable. For this type of features, the historical background (before the establishment of the EEZ) shall be considered. ${ }^{30}$

Thus, in the case of the smallest features located in the South China Sea, i.e. Scarborough Shoal, Johnson Reef, Cuarteron Reef, Fiery Cross Reef, Gaven Reef (North), and McKennan Reef, the Tribunal limited itself to assess the physical conditions of each feature and concluded that they are all rocks for the purpose of article 121(3) of UNCLOS, as they are minuscule and barren and they cannot sustain human habitation or economic life in their naturally formed state.

As to the largest features, i.e. Itu Aba (measuring approximately $1.4 \mathrm{~km}$ in length and $400 \mathrm{mt}$ at its widest point, with a surface area of approximately $0.43 \mathrm{sq} \mathrm{km}$ ), ${ }^{31}$ the Tribunal proceeded to consider relevant historical records:

In addition to the presence of fishermen ..., Itu Aba and South-West Cay were the site of Japanese mining and fishing activities in the 1920s and 1930s. The Spratlys were also the site of the somewhat more adventurous activities of Thomas Cloma and his associates in the 1950s. More recently, many of the features have been transformed by substantial construction efforts and are now the site of installations hosting significant numbers of personnel, generally of a governmental nature. ${ }^{32}$

\footnotetext{
${ }^{29}$ SCSA paras. 552, 553. The Tribunal argued that the threshold set by the International Court of Justice "for accepting an agreement on the interpretation by State practice is quite high." The Tribunal referred to the ICJ Advisory Opinion Concerning the Legality of the Use by a State of Nuclear Weapons in Armed Conflict, ICJ Reports 1996, p. 66 at p. 75, 81-82, paras. 19, 27, and the judgment in Kasikili/Sedudu Island, ICJ Reports 1999, p. 1045 at p. 1075-1087, paras. 48-63, as well as to the case law of the World Trade Organization.

${ }^{30}$ SCSA para. 616. Gullett (2018): at 31. The author suggests that the physical characteristics of a feature should treated as the principal test to determine a feature's insular status: "[a]ll efforts should be made to examine comprehensively a feature's resources, with consideration of what would be a sustainable size population on that type of feature in that location... Thus, it is submitted that a conclusion on this question should only be reached after thorough examination of the resources of the insular feature." See also Papanicolopulu (2018): 45.

${ }^{31}$ SCSA para. 401.

${ }^{32}$ SCSA para. 617.
} 
The Tribunal concluded that the existing evidence of historical activity in the features does not suffice to meet the requirements of "human habitation or economic life of their own" for the purposes of article 121(3). According to the Tribunal, the past inhabitation of these features has only been "temporary" and the economic activities "transient in nature," as their objective was to extract the economic resources of the features for the benefit of population located elsewhere to which the persons involved in the activities would return. The military and other governmental personnel presently stationed on the features "is heavily dependent on outside supply," and "[t]here is no evidence that they choose to inhabit there of their own volition, nor can it be expected that any would remain if the official need for their presence were to dissipate." 33 According to the Tribunal, even the largest features of the Spratly Islands are thus to be qualified as rocks.

\section{Relevant State Practice and implications of The South China Sea Arbitration Award}

The interpretation of article 121(3) of UNCLOS provided by the SCSA Award gave rise to significant scholarly commentary and criticism. ${ }^{34}$ This may be due to the following circumstances: that the Award represents the very "first international ruling on the specific question of the scope and application of Article 121(3);", 35 and that the formulation of article 121(3) is "a perfect recipe for confusion and conflict;"36 which is therefore able to generate heated debate even after the attempt of the Merits Award in the SCSA to clarify its content.

In particular, scholars have emphasised that the interpretation given by the Tribunal clashes against relevant international practice and that "if the relevant maritime claims and state practice had been thoroughly examined, the tribunal might have come to a different conclusion on the interpretation and application of Article 121 and in particular 121(3)."37

\footnotetext{
33 SCSA paras. 618-626.

34 Among the many, Papanicolopulu (2018), Gullett (2018), Song (2018), Nordquist (2018), Paik (2017), Tanaka (2017), Loja (2016), Oral (2016), Elferink (2016), Faccio (2017).

35 Gullett (2018): 37, Papanicolopulu (2018): 42 and 45. At 42, the author observed: "[the] decisions from the 1969 North Sea Continental Shelf case up to the 2014 Bangladesh/India case - were all adopted following a request to delimit maritime boundaries. The determination of the nature of one or more features and their entitlement to maritime zones, therefore, was not to be the outcome of the case, but just one step in the structured process that leads to the determination of a maritime boundary... In contrast to the cases mentioned so far, the South China Sea arbitration was the first case in which an international tribunal was called upon to determine the nature of certain maritime features, without at the same time being entrusted with the task of drawing the maritime boundary between the parties to the dispute."

36 Brown (1994): 150; Kagami (2008): 104.

37 Song (2018): 250. See also, Elferink (2016), mentioning the cases of Jan Mayen and Jabal al-Tayr. With reference to Jabal al-Tayr, Elferink observed: "the tribunal [in the arbitration between Eritrea and Yemen] referred to the barren and inhospitable nature of the island... This information leaves little doubt that Jabal al-Tayr would be an article 121(3) rock under the approach of the tribunal in Philippines $v$. China. [Even though] The tribunal in the arbitration between Eritrea and Yemen did not make any reference to article 121(3) [and] ... Jabal al-Tayr is consistently identified as an island." Contra, Tanaka (2017): at 373-374.
} 
For instance, Papanicolopulu has highlighted "the marginalisation of the role that successive State practice could play in the interpretation and the evolution of the content of the UNCLOS, including Article 121."38 The author has compared "the lengthy discussion of the travaux preparatoires," with "the quick disposal of State practice" and emphasised that "[t]he different treatment becomes even more significant if one considers that, while successive State practice forms part of the general rule on interpretation (art 31(3)(b) VCLT), the travaux preparatoires are relevant only as supplementary means of interpretation (art 32 VCLT)." 39

According to Yann-huei Song, "the Tribunal did not make sufficient efforts to consider the relevant numerous maritime boundary agreements and overall practice of states as regards rocks/islands." 40 The practice of coastal States having maritime claims to a 200-nm EEZ and continental shelf for remote features, such as Australia, France, Japan, New Zealand, and the United States, contradicts the interpretation established by the Award. ${ }^{41}$ Similarly, Elferink has observed that "there is an abyss between the tribunal's approach and the practice of many States." 42

In this regard, Gullett has further pointed out that "no State is known to have altered its practice" in light of the outcome of the SCSA Award and that "[t]he hitherto lack of alteration of State practice may be significant in future litigation. For example, if years pass and State practice has not altered since the Award, then a future international court or tribunal might be emboldened to interpret the provision differently from the 2016 Award and in a manner more consistent with State practice." 43

This is especially true with respect to the role of technology and the relationship between external resources and the human habitation or economic life that a feature can sustain of its own. ${ }^{44}$ As opposed to the Award, the practice shows that a certain degree of technology can be employed to make features habitable and that the requirement of "economic life of their own" may be satisfied even in cases where there is some infusion from the outside. ${ }^{45}$

In this regard, the report elaborated by the French Commission on Constitutional Laws (Commission des Lois Constitutionnelles) concerning the status of Clipperton island represents an interesting example. The report states:

\footnotetext{
38 Papanicolopulu (2018): 47.

39 Papanicolopulu (2018): 47 fn 27.

40 Song (2018): 256.

41 Song (2018): 251.

42 Elferink (2016). See also, Nordquist (2018): 188: “... unprotested state practice as exemplified in instances such as Christmas Island, Johnston Island and Atoll, Clipperton Island, Trindade Island, Heard and McDonald Islands, and Norway's Bouvet and Peter I Islands as well as many others, refutes, indeed completely contradicts, the Arbitral Tribunal's assertion."

43 Gullett (2018): 38.

44 Elferink (2016) has observed: "[e]ven if the economic life of the island is dependent on support from the outside, that life may center on resources that are located on the island or on services the island can provide and that are being used in a viable economic activity that can be sustained over a period of time." 45 Nordquist (2018): 188.
} 
We must ask ourselves the question of status, keeping in mind the difference existing between an islet and an island: unlike an islet, the island can generate an EEZ as long as it is habitable or inhabited. We run the risk of seeing this island [Clipperton] downgraded as an islet, within the meaning of the Montego Bay Convention, which would make us lose the advantages linked to the EEZ.

This risk would be avoided if we create there, as I suggest, a scientific station with an international vocation, the installation and operating costs of which could be financed by the sale of fishing rights in this EEZ which is one of the richest in the world in tuna.... It is therefore important to have this prospect of creating a scientific base on an island with an appropriate legal status, in order to ensure our presence. ${ }^{46}$

From the report it emerges that the use of technology and artificial additions are admitted (the report states that it will suffice to create an international scientific station in order to avoid the risk that the feature is de-classified into a rock), but also that the resources deriving from the exploitation of the EEZ could be used to sustain the economic activity in the feature itself (i.e. financing the station). ${ }^{47}$

In addition, cases of re-classification or de-classification of features in light of their reduced size and natural characteristics are quite unusual. ${ }^{48}$ On the contrary, the practice of many States is consistent in the use of technology and artificial addition to "secure the status of island" and the related right to the EEZ of their inhabited features scattered around the world. ${ }^{49}$ According to Kagami, this practice includes "posting small military forces or meteorological observation station staff, etc." 50

\footnotetext{
${ }^{46}$ Rapport (Philippe Folliot). Original version: "Nous devons nous poser la question du statut, en ayant en tête la différence qui existe entre un îlot et une île: contrairement à l'îlot, l'île peut générer une ZEE à condition d'être habitable ou habitée. Nous courrons le risque de voir déclasser cette île [Clipperton] en îlot, au sens de la Convention de Montego Bay, ce qui nous ferait perdre les avantages liés à la ZEE. Ce risque serait écarté si l'on y créait, comme je le propose, une station scientifique à vocation internationale, dont les coûts d'installation et de fonctionnement pourraient être financés par la vente des droits de pêche dans cette ZEE qui est l'une des plus riches du monde en thonidés.... Il est donc important d'avoir cette perspective de création d'une base scientifique sur une île dotée du statut juridique idoine, afin d'assurer notre présence."

${ }^{47}$ Kagami (2008): 105. According to Kagami, France "has most of its established EEZ around remote uninhabited islands, where small military or meteorological stations have been constructed, several personnel are stationed, but on which there are no residents or fisheries." Against this practice, see the Declaration of Judge Vukas (18 December 2000) in the Monte Confurco Case (Seychelles v. France), Prompt Release, Judgement of 18 December 2000.

${ }^{48}$ Only two cases are known in this regard: Alijos Rocks (Mexico) and Rockall Island (UK). See, Kagami (2008): 104; Schofield (2008): 75.

${ }^{49}$ For example: Pedra Branca (Singapore), see Ministry Foreign Affairs Singapore, Pedra Branca, at https://www.mfa.gov.sg/SINGAPORES-FOREIGN-POLICY/Key-Issues/Pedra-Branca. Accessed 26 August 2020; Aves Island (Venezuela); Okinotorishima (Japan); Raoul Island (New Zealand). Other cases concern the establishement of marine protected areas to assert the $200 \mathrm{~nm}$ EEZ, e.g. Kermadec Islands (New Zealand) and McDonald Islands (Australia), however this practice does not involve the use of technology or artificial addition.

${ }^{50}$ Kagami (2008): 105.
} 
Technology is also employed to preserve outermost features from erosion. Indeed, the rising of global sea level has the potential of changing the baselines of coastal States and even threatening the insular status of certain tiny features. ${ }^{51}$ To avoid this type of risks some States engaged in land reclamation. A case in point is the Indonesian Pulau Nipa, a feature sized roughly as Itu Aba (i.e. $60 \mathrm{ht}$, corresponding to 0.6 sq $\mathrm{km}$ ) located south of Singapore. At the beginning of the new century, this feature was facing severe erosion and risked losing base point coordinates for the measurement of the territorial sea and the EEZ. Thus, starting from 2004 the government of Indonesia started with land reclamation: it constructed a retaining wall and embankment and the Indonesia navy set up a post. ${ }^{52}$

However, how far can the use of technology go? In this regard, the practice shows that some States have engaged in veritable processes of "islandization" and transformed the natural status of their small features into artificial islands, with the aim of stopping erosion, as well as, obtaining large maritime entitlements and access to natural resources. For example, in the case of Okinotorishima, the Japanese government employed massive resource to turn the 5 atolls of roughly $5 \mathrm{sq} \mathrm{km}$ (and currently mostly submerged) into an artificial island made of steel breakwaters and concrete walls hosting a lighthouse, an heliport, and fishing expeditions. ${ }^{53}$ Similarly, China embarked on island building activities in the South China Sea, converting all or part of several submerged coral reefs into artificial islands. ${ }^{54} \mathrm{~A}$ case in point is Mischief Reef, a reef platform that submerged at high tide that has been transformed into an island that is permanently exposed. ${ }^{55}$ Mischief Reef currently hosts a military base and a harbour, and its surrounding waters are said to be rich in oil and gas.

The Award seems exactly to attempt to limit this type of abuses and avoid the situation where, through massive employment of technological means, "tiny features" are transformed into artificial islands able to "[generate] enormous entitlements to maritime space that would serve not to benefit the local population," ${ }^{56}$ determining the unequal distribution of natural resources, environmental damages and tensions between proximate coastal States. ${ }^{57}$

\footnotetext{
51 Baselines are of fundamental importance to coastal State claims to maritime jurisdiction as they provide the starting point from which claimed zones are measured, including the EEZ and the continental shelf. See, Schofield (2008): 71, 74, 75.

52 Gaynor (2020).

53 Xue (2011): 7-11. According to Kolb, this type of artificial transformation of features for the purpose of obtaining maritime entitlements might be considered as an abuse of rights under article 300 of the UNCLOS. See Kolb (1994): 903-904: “... la notion d'abuse de droit ...permettra par exemple d'éliminer les îlots où des travaux sont entrepris mala fide pour les rendre habitables, où des colons sont installés à la seule fin de détournement, ou à propos desquels toute autre mesure artificielle est prise en vue de contourner l'effet du paragraphe 3;" Tanaka (2017): 369 fn 48. As to environmental degradation caused by China in the South China Sea, see Huffman (2017): 358.

54 Barnes and $\mathrm{Hu}$ (2016): 1.

55 SCSA para. 1037: China's activities "have ... evolved into the creation of an artificial island ... elevat[ing] what was originally a reef platform that submerged at high tide into an island that is permanently exposed."

56 SCSA para. 516.

57 G7 Foreign Ministers' Meeting, Joint Communiqué (10-11 April 2017), at 23; Tanaka (2017): 368 observes: "[a]ccording to the Philippines, "[a] contrary rule would create perverse incentives for states to
} 


\section{The Application of Article 121(3) to Limit the Exploitation of Natural Resources that does not Benefit the Local Population}

The link existing between natural resources and the delimitation of maritime spaces has been discussed in the literature and it also emerges from relevant case law. ${ }^{58}$ The ICJ in the case Continental Shelf (Libyan Arabl Jarnahiriya/Malta) has stated that natural resources "are the essential objective envisaged by States when they put forward claims to sea-bed areas containing them."

In this regard, it has been observed that the entry into force of the Montego Bay Convention (16 November 1994) and the introduction of the possibility for the coastal States to extend their sovereignty over the EEZ has further incentivized the appetite of States for natural resources and the race to the physical appropriation of maritime features, with the consequent risk of conflict. ${ }^{60}$

According to Pertile:

If the entry into force of the UNCLOS has introduced an element of stability in the law of the sea, it is also true that in this phase States are defining their claims to maritime entitlements in light of the new juridical framework. The possibility to establish an EEZ also in relation to islands or taking into account them tend to give rise to the proliferation of conflictual claims or to exacerbate existing disputes.

The broadening of maritime spaces and related natural resources over which States can exercise their exclusive jurisdiction increases significantly the disputes concerning delimitations. ${ }^{61}$

This is especially true for the South China Sea, a region of strategic importance, with significant natural resources, and the subject of competing maritime claims. ${ }^{62}$

\section{Footnote 57 (continued)}

undertake such actions to extend their maritime zones to the detriment of other coastal states and/or the common heritage of mankind."',

58 Pertile (2012): 75: “[1]a limitazione degli spazi marini, a differenza di quanto accade per il contenzioso territoriale, è intrinsecamente legata al controllo delle risorse naturali."

59 Continental Shelf (Libyan Arab Jarnahiriya/Malta), Judgment, I. C.J. Reports (1985), p. 13, at para. 50.

60 Pertile (2012): 95-96.

61 Pertile (2012): 95-96. Orginal in Italian: "[s]e l'entrata in vigore della UNCLOS ha introdotto un elemento di stabilità nel diritto del mare, è anche chiaro che gli Stati stanno in questa fase definendo le proprie pretese al controllo degli spazi marini in considerazione del mutamento nel quadro giuridico. La possibilità di proclamare la zona economica esclusiva e di farlo anche rispetto alle isole o tenendo conto di esse tende a generare una proliferazione di pretese confliggenti o ad acuire controversie già esistenti. L'ampliamento degli spazi marini in cui gli Stati esercitano una giurisdizione esclusiva sulle risorse genera un notevole aumento delle controversie relative alla delimitazione."

62 Pertile (2012): 23; Huffman (2017): 357: "[t]he South China Sea is one of, if not the most, contested territories in the world, with China, Vietnam, Malaysia, Brunei, Indonesia, Taiwan, and the Philippines all advancing contradictory claims to the Sea. Up to \$5 trillion in trade passes through the region each year, and it is thought to contain significant hydrocarbon reserves, both of which have helped to fuel continued controversy over control of the Sea." According to the Economic Times, the region has plenty of strategic resources, with oil reserves of around 7.7 billion barrels and an estimate of 28 billion barrels in all. Natural gas reserves are estimated to total around 266 trillion cubic feet. See Sen (2020). 
The Tribunal in the SCSA itself recognised that "[t]he South China Sea is a crucial shipping lane, a rich fishing ground, home to a highly biodiverse coral reef ecosystem, and believed to hold substantial oil and gas resources." 63 Furthermore, the exploitation of the living and non-living resources existing in the South China Sea bed remains one of the most crucial matters at the basis of the controversy between the Philippines and China. ${ }^{64}$

It is thus no surprise that the Tribunal considered the question of the exploitation of the natural resources in the interpretation and application of article 121(3), in the attempt to find a balance between the interest of the population of the coastal States involved and mankind as a whole, to which the resources beyond the limits of national jurisdiction should belong. ${ }^{65}$ To this extent, the Tribunal argues that there will be no independent economic life, if the feature serves "purely as an object for extractive activities, without the involvement of a local population." Indeed, the raison d'être of the EEZ is the benefit of the local population and "[w]ithout benefiters, that is, the local population, the raison d'être of the EEZ disappears." 66 The question is: has the Tribunal found the right balance with reference to the features at stake in the SCSA?

In this regard, two remarks can be made: the first relates to the role of technology in supporting "human habitation or economic life" of a feature; the second refers to the relationship between external resources and the economic life that the feature can sustain of its own.

As to the first aspect, the Award states that the phrase "cannot sustain" shall be intended as "cannot, without artificial addition, sustain" and that the status of a feature must be assessed on the basis of its natural conditions, before "intensive modification." 67 According to the Tribunal, this interpretation is consistent with the object and purpose of article 121(3) as "[i]f States were allowed to convert any rock

\footnotetext{
63 SCSA para. 3.

64 SCSA paras. 22, 74, 209, 210, 211, 232, 394. For example, Philippine has claimed that China interferes "with its sovereign rights over non-living and living resources (emphasis added)" and fails to "prevent exploitation of the Philippines' living resources by Chinese fishing vessels" (para. 22); and that "this arbitration ... will clarify what is ours, specifically our fishing rights, rights to resources, and rights to enforce our laws within our EEZ (emphasis added)" (para. 74). With reference to historic rights, the Tribunal observed that "the framing of China's objections strongly indicates that China considers its rights with respect to petroleum resources to stem from historic rights (emphasis added)" (paras. 209210). The issue of the resources is also mentioned in the part devoted to the discussion of article 121(3) of UNCLOS (see, for example, paras. 512 et seq.).

65 Tanaka (2017): 377; SCSA para. 516.

66 Tanaka (2017): 377; Declaration of Vice-President Vukas, The Volga Case (Russian Federation v. Australia), Application for Prompt Release, Judgement of 23 December 2002 para. 5.

67 SCSA paras. 508-511.
} 
incapable of sustaining human habitation or an economic life into a fully entitled island simply by the introduction of technology and extraneous materials, then the purpose of Article 121(3) as a provision of limitation would be frustrated."68

However, the capacity of a feature to sustain human habitation or economic life is inextricably linked to human and technological developments that may vary over time. In addition, it shall be asked at what point the human modification becomes intensive so that to cross the line set by the SCSA. This could turn to be a very difficult question, considering that what was intensive some decades ago may be declassed as minor today or in the future when faced with new technological advances. ${ }^{69}$

For example, the creation of energy through solar-powered photovoltaic panels, the employment of desalinization plants, the use of the Internet and of mobile telecommunication, were only unthinkable in the 1970s when the concept of EEZ started to take shape; but they are common use today. The employment of these instruments may certainly contribute to the capacity of a feature to sustain human habitation or economic life and enhance the quality of the human habitation up to the minimal "proper standard" requested by the Award. ${ }^{70}$ This is especially true for features that fall "close to the line", such as the case of Itu Aba. In these cases, technology may play an important role in elevating the standard of human habitation that the feature can sustain on a certain point in time and may lead to the stationing of new population. In this regard, some of the improvements introduced in Itu Aba are representative:

[t]he hospital on Itu Aba was staffed with two physicians, a dentist and three nurses with videoconferencing connections to hospitals in Kaohsiung. There was also a post office and a guanyin temple on the island. Moreover, mobile telecommunications, postal services, satellite television, air services and ship services (including wharf, lighthouse, navigation facilities and related administrative services) have been established on Itu Aba. ${ }^{71}$

In light of the above, it is submitted that the role of technology cannot be disregarded in the assessment of a feature's capacity and it shall weight, at least as much as the historical excursus, towards the insular qualification of a feature in a certain point in time. $^{72}$

However, the application of technology shall only contribute to improve or preserve the capacity of the feature to sustain human habitation or economic life; but it shall not lead to the artificial creation of the feature itself and processes of "islandization" shall be rejected.

\footnotetext{
68 SCSA para. 509.

69 Faccio (2017): 631.

70 Nordquist (2018) 195.

71 Nordquist (2018): 195.

72 According to some scholars, this moment shall be that of the claim, see Nordquist (2018): 191.
} 
In this regard, the proportion between the natural formed area of the feature and the artificial addition may help assessing whether the human modification had been intensive. For example, with reference to the features located in the South China Sea, a study carried out by Barnes and Hu gives evidence that "over $15 \mathrm{~km}^{2}$ of submerged coral reef area was converted to artificial islands between June 2013 and December 2015," by China, Vietnam and Taiwan; ${ }^{73}$ but not all features were affected in the same way and the proportion between natural formed area and artificial addition vary significantly from feature to feature. ${ }^{74}$ As far as Itu Aba is concerned, the scientific report shows that $0.49 \mathrm{sq} \mathrm{km}$ were subject of construction activities (against a reef area of $1.56 \mathrm{sq} \mathrm{km}$ ) and that this addition mostly concerns the expansion of the port. By contrast, in Fiery Cross Reef the artificial addition is 3.06 (against a reef area of 4.41). Where the application of technology has led to the improvement of a feature's capacity but has not resulted into the intensive modification of the feature, as in the case of Itu Aba, the insular qualification should be granted. ${ }^{75}$

As to the relationship between external resources and the economic life that an island can sustain of its own, it is argued that the role of the local population remains pivotal, and a link shall be established between the outside support and the people located in the feature. ${ }^{76}$

The "type" of local population involved (i.e. farmers, fishermen, businessmen vis à vis military or governmental personnel), however, shall not matter towards the qualification of the feature. Thus, the Tribunal's conclusion that permanent inhabitation by military or governmental personnel in Itu Aba does not "suffice to constitute "human habitation" for the purposes of Article 121(3)," as this people is "heavily dependent on outside supplies" and "[t]here is no evidence that they choose to inhabit there of their own volition, nor can it be expected that any would remain if the official need for their presence were to dissipate"is not persuading. ${ }^{77}$

On the contrary, relevant practice of States' parties to the UNCLOS confirms that small features, offering limited resources and work opportunities, are often populated by military forces and governmental staff (i.e. meteorological observation station staff, lighthouse staff, et similia). For example, this is the case of the

\footnotetext{
73 Barnes, Hu (2016): 1.

74 Barnes, Hu (2016): 7 (Table 1).

75 Barnes, Hu (2016): 6 “[a]ll but two of Vietnam's projects (as well as Taiwan's construction on Itu Aba Island) observed in the OLI time series were additions to already existing islands, while all of the Chinese projects represented entirely new islands."

76 SCSA para. 500. The Tribunal stated: "[t]he "of their own" component is essential to the interpretation because it makes clear that a feature itself (or group of related features) must have the ability to support an independent economic life, without relying predominantly on the infusion of outside resources or serving purely as an object for extractive activities, without the involvement of a local population (emphasis added)." It is debatable, in the opinion of the author, whether and at what point a feature shall be classified as a "rock," because of predominant infusion from the outside resources. See also, Elferink (2016). Elferink focuses on the link between the outside support and the "resources and services" of the island, rather than on the population located therein, arguing that the text of article 121(3) (which distinguishes between the separate requirements of "human habitation" and "economic life") and its drafting history indicate that the "economic life of their own" does not necessarily require the presence of a local population.

77 SCSA paras. 618-626.
} 
Philippine's Thitu Island (of approximately $0.37 \mathrm{sq} \mathrm{km}$ ) that hosts a naval port, dual use civil and military airstrip, a clinic and a school; the local population reported to be stationing in the feature is mostly composed of civil servants and their families. ${ }^{78}$

In light of the above considerations, it does not seem that the Tribunal have set the right balance between the interest of the local population and the mankind as a whole with reference to Itu Aba; on the contrary, the Tribunal concluded that the people located therein are uninfluential for the purpose of the application of article 121(3) of UNCLOS.

\section{Conclusion}

As in fiction and mythology, islands are inextricably linked to the adventures of the heroes that in these islands are born or land and decide to make their own place, for a time or forever, by using the means that the nature, their fantasy and talent put at their disposal. ${ }^{79}$ The adventures of heroes make the history of the feature, which in turn influences the State practice and the application of the law in a given point of time.

Any assessment of the nature of features, in accordance with article 121(3) of UNCLOS, cannot disregard these elements and their interaction.

The SCSA Award, however, seems to neglect this matrix and the existence of any relevant State practice with reference to the interpretation of article 121(3). This, as discussed, led many authors to criticize the Award and question what could be its future implications. ${ }^{80}$ Indeed, if a number of States have paid lip service to the Award, none is known to have taken concrete actions to change its practice following the SCSA outcome with reference to their own features (comparable in size/ conditions to the features in the Spratly). ${ }^{81}$ This won't certainly persuade China to

\footnotetext{
78 See, Daily Life on Thitu Island, in Asian Martitime Transaprency Initiative, https://amti.csis.org/daily -life-on-thitu-island/.

79 According to the Oxford English Dictionary the word "technology" refers to the application of knowledge for practical purposes, especially in industry, manufacturing, etc. See, Oxford English Dictionary, at https://www.oed.com. Accessed 31 August 2020.

80 Supra section 3. See also, Ministry of Foreign Affairs Republic of China (Taiwan), Taiping Island is an island, not a rock, and the ROC possesses full rights associated with an exclusive economic zone and continental shelf in accordance with UNCLOS, 23 January 2016, at https://www.mofa.gov.tw/en/News_ Content.aspx?n=1EADDCFD4C6EC567\&s=542A8C89D51D8739. Accessed 29 August 2020.

81 For example, see Japan's statement on the Arbitration between the Republic of the Philippines and the People's Republic of China regarding the South China Sea (12 July 2016), at https://www.mofa.go.jp/ press/release/press4e_001204.html. Accessed 30 August 2020; E3 joint statement on the situation in the South China Sea. Statement by United Kingdom, France and Germany on the situation in the South China Sea (29 August 2019), at https://www.gov.uk/government/news/e3-joint-statement-on-the-situa tion-in-the-south-china-sea. Accessed 30 August 2020. As to features that are almost likely to be captured by article 121(3) of UNCLOS according to the SCSA Award are Okinotorishima (Japan), and Clipperton. See also, Elferink (2016): "[a]mong the islands that likely would have to be categorized as article 121(3) rocks one can think of isolated islands in the polar regions, like Jan Mayen, the Russian islands of Henrietta and Jeannetta, Heard and MacDonald Islands or Bouvet Island. Examples from other regions
} 
comply with the Award and secure "a period of peaceful management of the tangled disputes within the South China Sea." 82

Funding Open access funding provided by Università degli Studi di Trento within the CRUI-CARE Agreement.

Open Access This article is licensed under a Creative Commons Attribution 4.0 International License, which permits use, sharing, adaptation, distribution and reproduction in any medium or format, as long as you give appropriate credit to the original author(s) and the source, provide a link to the Creative Commons licence, and indicate if changes were made. The images or other third party material in this article are included in the article's Creative Commons licence, unless indicated otherwise in a credit line to the material. If material is not included in the article's Creative Commons licence and your intended use is not permitted by statutory regulation or exceeds the permitted use, you will need to obtain permission directly from the copyright holder. To view a copy of this licence, visit http://creativecommons.org/licen ses/by/4.0/.

\section{References}

Barnes, Brian B., and Hu, Chuanmin. 2016. Island building in the South China Sea: detection of turbidity plumes and artificial islands using Landsat and MODIS data. Scientific Reports Nature, at https://www. nature.com/articles/srep33194.pdf. Accessed 31 August 2020.

Brown, Edward D. 1994. The International Law of the Sea. Volume 1. Introductory Manual. Aldershot, UK, and Vermont: Dartmouth Publishing Company.

Defoe, Daniel. 1983. Robinson Crusoe. Oxford's World Classics. Oxford: Oxford University Press.

E3 joint statement on the situation in the South China Sea. Statement by United Kingdom, France and Germany on the situation in the South China Sea (29 August 2019), at https://www.gov.uk/government/ news/e3-joint-statement-on-the-situation-in-the-south-china-sea. Accessed 30 August 2020.

Elferink, Alex G. Oude. 2016. The South China Sea Arbitration's Interpretation of Article 121(3) of the LOSC: A Disquieting First. The NCLOS Blog (7 November 2016), at https://site.uit.no/nclos /2016/09/07/the-south-china-sea-arbitrations-interpretation-of-article-1213-of-the-losc-a-disquietin g-first/. Accessed 17 August 2020.

Faccio, Sondra. 2017. The South China Sea Arbitration. Award of July 12, 2016: The Unbearable Lightness of Being a Rock. La Comunità Internazionale LXXII: 623.

Gaynor, Jennifer L. 2020- Liquid Territory, Shifting Lands. Property, Sovereignty, and Space in Southeast Asia's Tristate Maritime Boundary Zone. In: Blue Legalities. The Life and Laws of the Sea, eds. I. Braverman et al. Durham and London; Duke UP.

Golding, William. 1954. Lord of the Flies. Ebook: Global Village Contemporary Classic, at https://www. yumpu.com/en/document/read/6655037/lord-of-the-flies-global-village. Accessed 17 August 2020.

Gullett, Warwick. 2018. The South China Sea Arbitration's Contribution to the Concept of Juridical Islands. Questions of International Law 47: 5.

\section{Footnote 81 (continued)}

would be Clipperton (Pacific), Tromelin (Indian Ocean) or Jabal al-Tair, which played a role in the arbitration concerning sovereignty and maritime delimitation between Eritrea and Yemen."

82 Ted L. McDorman, The South China Sea Arbitration, in American Society of International Law, 18 November 2016, at https://www.asil.org/insights/volume/20/issue/17/south-china-sea-arbitration. Accessed 31 August 2020; Ministry of Foreign Affairs of the People's Republic of China, Statement of the Ministry of Foreign Affairs on the Award on Jurisdiction and Admissibility of the South China Sea Arbitration by the Arbitral Tribunal Established at the Request of the Republic of the Philippines, 30 October 2015, at www.fmprc.gov.cn/mfa_eng/zxxx_662805/t1310474.shtml; Ministry of Foreign Affairs of the People's Republic of China, Statement of the Ministry of Foreign Affairs on the Award of 12 July 2016 of the Arbitral Tribunal Established at the Request of the Republic of the Philippines, 12 July 2016, at www.fmprc.gov.cn/nanhai/eng/snhwtlcwj_1/t1379492.htm. Both accessed 31 August 2020. 
Homer, 1996. The Odyssey. New York: Penguin Books.

Huffman, Jamie. 2017. The Kimberley Process as A Framework for Regulating Conflict Oil and Gas Sourced from the South China Sea. William \& Mary Environmental Law and Policy Review 42 (1): 357.

Japan's statement on the Arbitration between the Republic of the Philippines and the People's Republic of China regarding the South China Sea (12 July 2016), at https://www.mofa.go.jp/press/release/press 4e_001204.html. Accessed 30 August 2020.

Kagami, Yasuhiko. 2008. Environmental Policy for Desert Islands: Beyond "Island or Rock?". Proceeding of International Symposium on Islands and Oceans 104.

Loja, Melissa H. 2016. The Spratly Islands as a Single Unit Under International Law: A Commentary on the Final Award in Philippines/China Arbitration. Ocean Development \& International Law 47 (4): 309.

McDorman, Ted L. The South China Sea Arbitration. American Society of International Law (18 November 2016), at https://www.asil.org/insights/volume/20/issue/17/south-china-sea-arbitration. Accessed 31 August 2020.

Ministry of Foreign Affairs of the People's Republic of China, Statement of the Ministry of Foreign Affairs on the Award of 12 July 2016 of the Arbitral Tribunal Established at the Request of the Republic of the Philippines (12 July 2016), at www.fmprc.gov.cn/nanhai/eng/snhwtlcwj_1/t1379492.htm. Accessed 31 August 2020.

Ministry of Foreign Affairs of the People's Republic of China, Statement of the Ministry of Foreign Affairs on the Award on Jurisdiction and Admissibility of the South China Sea Arbitration by the Arbitral Tribunal Established at the Request of the Republic of the Philippines (30 October 2015), at www.fmprc .gov.cn/mfa_eng/zxxx_662805/t1310474.shtml. Accessed 31 August 2020.

Ministry of Foreign Affairs Republic of China (Taiwan), Taiping Island is an island, not a rock, and the ROC possesses full rights associated with an exclusive economic zone and continental shelf in accordance with UNCLOS (23 January 2016), at https://www.mofa.gov.tw/en/News_Content.aspx?n=1EADD CFD4C6EC567\&s=542A8C89D51D8739. Accessed 29 August 2020.

Nordquist, Myron H. 2018. UNCLOS Article 121 and Itu Aba in the South China Sea Final Award: A Correct Interpretation? In The South China Sea Arbitration: The Legal Dimension, ed. S. Jayakumar et al. Cheltenham: Edward Elgar.

Kolb, Robert. 1994. L'interprétation de l'article 121, paragraphe 3, de la Convention de Montego Bay sur le droit de la mer: les roches qui ne se prêtent pas à l'habitation humaine ou à une vie économique propre. Annuaire Français de Droit International 40: 876.

Nordquist, Myron H., and William G. Phalen. 2017. Interpretation of UNCLOS Article 121 and Itu Aba (Taiping) in the South China Sea Arbitration Award. In International Marine Economy: Law and Policy, ed. M.H. Nordquist. Brill: Leiden and Boston.

Oral, Nilufer. 2016. "Rocks" or "Islands"? Sailing Towards Legal Clarity in the Turbulent South China Sea. American Journal of International Law Unbound 110: 279.

Paik, Jin-Hyun. 2017. South China Sea Arbitral Awards: Main Findings and Assessment. Max Planck Yearbook of United Nations Law.

Pertile, M. 2012. La Relazione tra Risorse Naturali e Conflitti Armati nel Diritto Internazionale. Milano: CEDAM.

Papanicolopulu, Irini. 2018. The land dominates the sea (dominates the land dominates the sea). Questions of International Law 47: 39.

Rapport (Philippe Folliot). Au nom de la Commission des Lois Constitutionnelles, de la législation et de l'Administration Générale de la République sur la proposition de loi ( $\left.n^{\circ} 4102\right)$ portant modification de la Loi $n^{\circ}$ 55-1052 du 6 août 1955 portant statut des terres australes et antarctiques françaises et de l'île de Clipperton et visant à donner un statut à l'île de Clipperton, at http://www.assemblee-nationale. fr/14/rapports/r4219.asp. Accessed 5 September 2020.

Schofield, Clive. 2008. Against a Rising Tide: Ambulatory Baseline and Shifting Maritime Limits in the Face of Sea Level Rise. Proceeding of International Symposium on Islands and Oceans 70.

Sen, Ankita. 2020. South China Sea: Beijing has a major natural advantage in the geopolitical power game. The Economic Times June 17, 2020, at https://economictimes.indiatimes.com/news/defence/ south-china-sea-beijing-has-a-major-natural-advantage-in-the-geopolitical-power-game/articlesho w/76423659.cms?from=mdr. Accessed 28 August 2020.

Silverstein, Andrew L. 1990. Okinotorishima: Artificial preservation of speck of sovereignty. Brooklyn Journal of International Law 16 (2): 409.

Song, Yann-Huei. 2010. The Application of Article 121 of the Law of the Sea Convention to the Selected Geographical Features Situated in the Pacific Ocean. Chinese Journal of International Law 9 (4): 663. 
Song, Yann-Huei Song. 2018. The July 2016 Arbitral Award, Interpretation of Article 121(3) of the UNCLOS, and Selecting examples of Inconsistent State Practice. Ocean Development \& International Law 49 (3): 247.

Tanaka, Yoshifumi. 2017. Reflections on the Interpretation and Application of Article 121(3) in the South China Sea Arbitration (Merits). Ocean Development \& International Law 48 (3-4): 365.

Van Dyke, Jon R., Joseph R. Morgan, and Jonatham Gurish. 1988. The Exclusive Economic Zone of the Northwestern Hawaiian Islands: When Do Uninhabited Islands Generate an EEZ? San Diego Law Review 25 (3): 425.

Xue, Guifang Xue. 2011. How Much Can a Rock Get-A Reflection from the Okinotorishima Rocks. China Oceans Law Review 1: 1.

Publisher's Note Springer Nature remains neutral with regard to jurisdictional claims in published maps and institutional affiliations. 